\title{
The Effect of Herdsmen's Endowments on Their Borrowing Channels Based on Structural Equation Model
}

\author{
Yuchun $\mathrm{Liu}^{1}$, Chang $\mathrm{Liu}^{2}{ }^{2}$ and Changbai $\mathrm{Xiu}^{3}$ \\ ${ }^{1,2,3}$ School of Economics and Management, Inner Mongolia Agricultural University, Huhhot 010010, China \\ *Corresponding author
}

\begin{abstract}
Herdsmen's access to credit funds has an important supporting role in promoting modern economic development in the pastoral areas and broadening the channels for herdsmen to increase their income. Based on pastoral survey data, this paper constructed the structural equation model(SEM) using the herdsmen's relational network as the mediation variable, and studied the relationship of human capital, family economic level, relationship network and herdsmen' borrowing channels. The result obtained is that the relationship network of herdsmen has a significant influence on the choice of herdsmen's borrowing channels. Herdsmen's human capital not only directly affects the borrowing channels the herdsmen, but also indirectly affects the regular borrowing channels through the mediation variable--relationship network. The family economic level has a significant effect on the regular borrowing and informal borrowing of the herdsmen, but the effect of the regular borrowing is greater than the effect of the informal borrowing.
\end{abstract}

Keywords-structural equation model; relationship network; borrowing channel

\section{INTRODUCTION}

For a long time, financial resources have been concentrated in large and medium-sized cities above the county level, and financial resources in rural and pastoral areas have been relatively weak. In 2017, the No. 1 Document of the State Council in China (promoting the structural reform of the agricultural supply side and accelerating the development of new kinetic energy for agriculture and rural development) called for the promotion of more financial resources to the rural areas so that farmers can obtain high-quality and low-cost financial services. Farmers and herdsmen's access to financial services can effectively change their initial endowments, increase the efficiency of agricultural and animal husbandry production, and increase income levels. However, the inherent weak and high-risk nature of animal husbandry leads to the reverse distortion of the allocation of pastoral financial resources, the poor efficiency of pastoral financial markets, the lack of explicit loans to potential herdsmen and the slow accumulation of primitive capital, thus making it difficult to match the lending technology of formal financial institutions and obtained loans. Informal finance has become a widely-existing financing arrangement inherent in pastoral areas. Data from China's Jiangsu Rural Finance Development Research Center in 2015 showed that $42.91 \%$ of households are subject to formal financial constraints and $59.45 \%$ of households are financed through the informal financial market.
Specifically, this is due to the heterogeneity of the farmers and herdsmen's own endowment conditions. The core of loan technology of formal financial institution is collecting information from the borrower households and identifying and reviewing the information. Herdsmen with better endowment conditions can provide enough mortgages. With guarantees, it is easy to obtain formal credit support, while poorly endowed herdsmen often resort to private credit.

The connotation of herdsmen's endowment is very wide, usually involving the herdsmen's human capital, economic capital, social capital and natural capital. This paper examines the endowment of herdsmen households into human capital, family economic level and relationship network. Previous studies have shown that the more endowment farmers and herdsmen have, the easier it is for them to obtain loans and that the different endowment factors have different effects on farmer households' lending channels (LinLu, 2016) [1]. The specific hypothesis is that social networks, trust, and participation in the selection of private lending by peasants and herdsmen have a significant impact. Social trust, regulation, and mutual benefit have a significant influence on the choice of formal lending by farmers and herdsmen; age, education level, household population, and borrowing purpose significantly influence the farmers and herdsmen behaviors[2]. Therefore, in the process of continuous deepening of rural and pastoral financial reform, the government should balance the pattern of formal finance and private lending in rural and pastoral areas, and use relationship network as an intermediary to enable herdsmen with different endowment conditions to obtain corresponding credit support.

From the perspective of pastoral households' endowments as the ability of pastoral households to obtain external resources, this paper will examine the herdsmen's human capital, family economic level and relationship network. Using the sample data from four ethnic regions in Inner Mongolia, Ningxia, Xinjiang, and Gansu, a structural equation model was constructed to explore the path and intensity of the influence of herdsmen's endowment on their borrowing channels.

\section{LITERATURE REVIEW AND RESEARCH HYPOTHESIS}

\section{A. Literature Review}

Domestic and foreign scholars have studied a large number of herdsmen households' lending practices, mainly focusing on the motivation of borrowing, lending channels, the welfare 
effect of borrowing, and factors affecting lending. Herdsmen' endowments are the key factors affecting lending. Glass believed that the quality of the family was measured by the resources owned by the parents, including political capital, economic capital, cultural capital, and social capital [3]. Maria C. Pereira considered that social capital is a multidimensional concept that concerns the consumers ability to obtain benefits from their engagement in social activities and social networks[4]. Although scholars did not explicitly put forward the concept of herdsmen households' endowment, the concept of total household assets is similar to that of herdsmen households. Chinese scholars such as Xiangzhi Kong et al. studied the endowment earlier. He believed that endowment is the natural and acquired resources and agricultural skills owned by all family members. These resources and agricultural skills specifically represent the family's human capital, economic capital, social capital, and natural capital [5]. Later scholars continued to expand the concept of endowment, which not only included the resources and agricultural skills of family members, but also included the expansion of individual agricultural skills and the extension of personal endowments. Individuals' behavior choices were constrained by family endowments and family decisions[6]. From previous studies, it can be seen that endowments can be roughly divided into four categories: human capital, economic capital, social capital, and natural capital. Zan Yang; Ying Fan; Jing Wu suggested the low financial cost of informal borrowing: households tent to borrow as much as possible from informal channels until they reach the constraint determined by their social capital, which significantly crowds out formal borrowing[7]. George Okello Candiya Bongomin provided empirical evidence on phenomena studied in rural areas in Sub-Saharan Africa with poor use of social capital embedded in customs and norms for doing business. The results highlight the importance of social capital in mediating the relationship between financial intermediation and financial inclusion of the poor in rural Uganda[8]. Therefore, in order to avoid credit constraints, borrowers tend to maintain the necessary long-term cooperation with informal financial lending institutions to prepare for emergencies[9]. Informal financial institutions often select objects through long-term cooperation with borrowers when making lending decisions. The longer the cooperation, the more likely farmers are to borrow money[10]. Tho Pham and Oleksandr Talavera showed that social capital could facilitate loan applications: firms that have a closer relationship with government officials and other business people can get loans of longer duration [11].

Overall, the existing literature has mainly studied how and to what extent various types of capital affect the financing channels of pastoral households, and did not conduct further research on the relationship between various types of pastoral households endowments. In this paper, the structural equation model can be used not only to study the direct impact of various types of capital on herdsmen' lending channels, but also to consider the path and intensity of influence among various types of capital.

\section{B. Research Hypothesis}

The pastoral households studied in this paper are divided into three dimensions: human capital, family economic level and relationship network. The herdsmen's human capital and family economic level determine the breadth and depth of the herdsmen's relationship network, and thus affect the herdsmen's lending channels. Based on the connection between the three, this paper proposes the following hypotheses from three dimensions of pastoral households endowments:

H1: Herdsmen with richer endowments are more likely to get loans.

H2: With different endowments, herdsmen' lending channels are different.

H2a: Herdsmen's human capital has a direct positive effect on formal lending.

H2b: Herdsmen's human capital has a direct positive effect on informal lending.

H2c: Herdsmen's household economic level may have a directly positive effect on formal lending.

H2d: Herdsmen's household economic level may have a directly positive effect on informal lending.

H2e: The relationship network of pastoral households has a direct and significant impact on formal lending and informal lending.

H3: There is a connection between human capital, family economic level, and relationship network in the household endowment.

H3a: Human capital has a positive and significant effect on the relationship network.

$\mathrm{H} 3 \mathrm{~b}$ : The family economic level has a positive effect on the relationship network.

\section{RESEARCH METHOD AND DATA}

\section{A. Research Framework}

In the pastoral credit market, the economic strength and social relationships of pastoral households can become effective mortgage assets for pastoral households. Similarly, human capital can also constitute an independent source of income. However, most pastoral households can only obtain small informal loans based on human relationships. Formal finance can hardly meet their financial needs. Based on this status quo, this paper explores herdsmen's lending channels from the perspective of the herdsmen's own conditions--herdsmen's endowments. Its route of action is as follows: the kind of channels from which herdsmen get their loans depends on the type of endowment elements and the total amount of elements owned by the households. The pastoral's human capital and the family's economic level will strengthen the relationship networks, and indirectly affect the herdsmen' lending channels. Of course, the relationship between human capital and family economic level can also act directly on pastoral households' lending channels. Based on the above analysis, a mechanism model for the effects of pastoral endowments on their lending channels is presented, as shown in Figure I. 
1 Herdsmen's Endowment

Borrowing Charnels

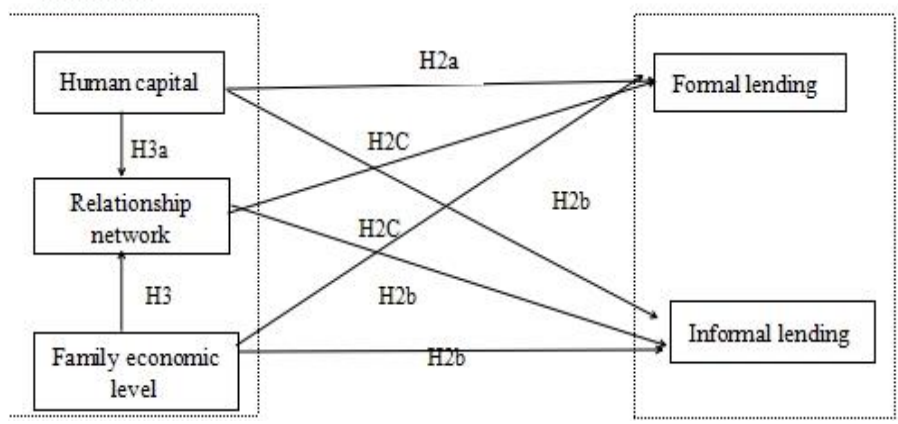

FIGURE I. INFLUENCE MECHANISM OF PASTORAL HOUSEHOLD ENDOWMENTS ON HERDSMEN'S LENDING CHANNELS

\section{B. Research Method}

The structural equation model is a multivariate statistical method for the study of the causality model among latent variables. It combines the two statistical methods of "factor analysis" and "path analysis" in traditional analysis of multivariate statistical analysis, tests the relationship among variables, latent variables, and error variables in the model, and examines the direct and indirect effects of independent variables on dependent variables. It is a confirmatory analytical method. Because the relationship among herdsmen's human capital, family's economic level, and relationship network are complex and difficult to measure directly, this paper selects the structural equation model for analysis to improve the accuracy of the estimation results.

\section{Sources of Data}

The data used in this paper comes from the pastoral livelihoods survey conducted by the Inner Mongolia Institute of Rural Pastoral Development in 2016 and 2017. The questionnaires include various topics such as infrastructure and environment, economic activities, family wealth status, family dynamics, and population migration in pastoral areas. The survey samples cover 10 husbandry banner counties in the four ethnic regions of Inner Mongolia, Ningxia, Xinjiang, and Gansu. The sample size of the surveyed herdsmen is 1,321 households, 130 invalid samples were removed, and 1191 effective samples are being used as study objects.

\section{Descriptive Statistical Analysis of Samples}

The survey results show that among the 1191 sample herdsmen, males account for $68.85 \%$ and females account for $31.15 \%$. This shows that the principals of the herdsmen households are still dominated by men; the middle-aged and old herdsmen of the interviewees are the majority, those under 40 only account for $22.75 \%$, and $77.25 \%$ of the respondents are over the age of 51 . The young and middle-aged in the pastoral areas are less engaged in productive activities; the education level of the interviewed herdsmen is generally low, $70 \%$ of herdsmen have received junior high school education or below, and only $4.54 \%$ have college education or above.
TABLE I. INDIVIDUAL CHARACTERISTICS OF SAMPLE HOUSEHOLDS

\begin{tabular}{|c|c|c|c|}
\hline Item & Category & $\begin{array}{c}\text { Number of } \\
\text { samples }\end{array}$ & $\begin{array}{c}\text { Proportion } \\
(\%)\end{array}$ \\
\hline \multirow{2}{*}{ Gender } & male & 820 & $68.85 \%$ \\
\hline & female & 371 & $31.15 \%$ \\
\hline \multirow{5}{*}{ Age(years) } & $20-30$ & 88 & $7.39 \%$ \\
\hline & $31-40$ & 183 & $15.36 \%$ \\
\hline & $41-50$ & 391 & $32.83 \%$ \\
\hline & $50-60$ & 356 & $29.89 \%$ \\
\hline & $>60$ & 173 & $14.53 \%$ \\
\hline \multirow{5}{*}{$\begin{array}{c}\text { Educational } \\
\text { level }\end{array}$} & No formal education & 128 & $10.75 \%$ \\
\hline & Basic & 240 & $20.15 \%$ \\
\hline & Primary & 502 & $42.15 \%$ \\
\hline & Higher & 267 & $22.42 \%$ \\
\hline & College & 54 & $4.53 \%$ \\
\hline
\end{tabular}

Of the 1191 pastoral households that met the borrowing requirements, 711 herdsmen eventually obtained loans, and the effective borrowing rate was $59.7 \%$. Among them, there were 435 herdsmen borrowing through formal channels, 173 herdsmen obtaining loans, and the effective borrowing rate was $39.8 \%$. 756 shepherds borrowed through informal channels, 535 herdsmen obtained loans and the effective borrowing rate was $70.8 \%$. The above situation shows that due to the lack of the herders' own conditions and the high risk of agricultural and husbandry production, it is difficult to meet the loan conditions of the formal financial institutions. The convenient, simple and informal way of financing has become the herdsmen's main borrowing channel, thus promoting the economic development of pastoral areas. The specific study case is shown in Table II.

TABLE II. STATISTICAL DESCRIPTION OF PASTORAL HOUSEHOLDS' BORROWING CHANNELS

\begin{tabular}{|c|c|c|c|c|}
\hline $\begin{array}{c}\text { Borrowing } \\
\text { channels }\end{array}$ & Category & $\begin{array}{c}\begin{array}{c}\text { Number } \\
\text { of } \\
\text { samples }\end{array} \\
\end{array}$ & \begin{tabular}{|c|}
$\begin{array}{c}\text { Number of } \\
\text { herdsmen } \\
\text { obtained loans }\end{array}$ \\
\end{tabular} & $\begin{array}{c}\text { Effective } \\
\text { loan } \\
\text { rate } \\
\end{array}$ \\
\hline \multirow[b]{2}{*}{$\begin{array}{l}\text { Formal } \\
\text { channels }\end{array}$} & Banks & 272 & 109 & $40.07 \%$ \\
\hline & $\begin{array}{l}\text { Non-bank } \\
\text { financial } \\
\text { institutions }\end{array}$ & 163 & 64 & $39.26 \%$ \\
\hline \multirow{3}{*}{$\begin{array}{l}\text { ilformal } \\
\text { channels }\end{array}$} & Relatives & 370 & 282 & $75.68 \%$ \\
\hline & Friends & 290 & 198 & $68.28 \%$ \\
\hline & $\begin{array}{c}\text { Private lending } \\
\text { institutions }\end{array}$ & 96 & 49 & $51.04 \%$ \\
\hline
\end{tabular}

E. Variable Measurement and Inspection

\section{1) Variable Measurement}

- Human capital. This article refers to Qinghua Chen's description of the rural households' age, educational level, and 
out-of-town employment experiences[12].

- Family economic level. This article uses the family's income over the past year, deposits, and individual business experience to measure the family's economic level.

- Relational networks. The relationship network is an important component of social capital. The relationship network formed by trust, reciprocity, and norms can improve the financing environment of herdsmen by promoting cooperation. This article refers to the communication among relatives, neighborhood friendliness and gift expenses mentioned in the article "Xinle Tong" in Social Capital's Impact on farmers' borrowing Behavior[13] to describe this concept.

\section{2) Reliability and Validity Test}

The reliability and validity test of the survey data were analyzed by spss19.0 software. The reliability test uses Cronbach' $\alpha$ coefficient. When the Cronbach' $\alpha$ is greater than or equal to 0.7 , the reliability was higher. The Cronbach' $\alpha$ of all latent variables in this paper is 0.852 , the variables have good reliability. Validity test uses the KMO and Bartlett sphere test to inspect whether the data are suitable for factor analysis. The calculation results show that the KMO value is 0.890 , which is much greater than 0.5. The Bartlett's sphere test approximates the chi-square value of 3817.61 . It passed the test at a significant level of $1 \%$, indicating that it is suitable for factor analysis. Then the factor loading of each measurement index on its latent variable is calculated by factor analysis and the results are all greater than 0.7 , indicating that the validity of the variables is good. The specific test results are shown in Table III.

TABLE III. VARIABLE RELIABILITY AND VALIDITY TEST

\begin{tabular}{|c|c|c|c|c|c|}
\hline Latent variable & Code & Observation variable & Factor loading & Cronbach' $\alpha$ & KMO \\
\hline Human capital & $\begin{array}{l}\text { a1 } \\
\text { a2 } \\
\text { a3 }\end{array}$ & $\begin{array}{c}\text { Age } \\
\text { Educational level } \\
\text { Work experience }\end{array}$ & $\begin{array}{l}0.719 \\
0.780 \\
0.703\end{array}$ & 0.862 & 0.743 \\
\hline $\begin{array}{c}\text { Family economic } \\
\text { level }\end{array}$ & $\begin{array}{l}\mathrm{b} 1 \\
\mathrm{~b} 2 \\
\mathrm{~b} 3\end{array}$ & $\begin{array}{l}\text { Income for the past year } \\
\text { Household deposits } \\
\text { Individual business experience }\end{array}$ & $\begin{array}{l}0.716 \\
0.812 \\
0.713\end{array}$ & 0.846 & 0.817 \\
\hline $\begin{array}{l}\text { Relationship } \\
\text { network }\end{array}$ & $\begin{array}{l}\mathrm{c} 1 \\
\mathrm{c} 2 \\
\mathrm{c} 3\end{array}$ & $\begin{array}{l}\text { Communication among relatives } \\
\text { Neighborhood friendliness } \\
\text { Gift expenses }\end{array}$ & $\begin{array}{l}0.845 \\
0.738 \\
0.774\end{array}$ & 0.901 & 0.915 \\
\hline Formal lending & $\begin{array}{l}\mathrm{d} 1 \\
\mathrm{~d} 2\end{array}$ & \begin{tabular}{|l} 
Easy to borrow from banks \\
Easy to borrow from non-bank financial institutions
\end{tabular} & $\begin{array}{l}0.758 \\
0.734\end{array}$ & 0.923 & 0.916 \\
\hline Informal lending & $\begin{array}{l}\text { e1 } \\
\text { e2 } \\
\text { e3 }\end{array}$ & $\begin{array}{c}\text { Easy to get loans from relatives } \\
\text { Easy to borrow from friends } \\
\text { Easy to borrow from private lending institutions }\end{array}$ & $\begin{array}{l}0.765 \\
0.801 \\
0.797 \\
\end{array}$ & 0.907 & 0.904 \\
\hline
\end{tabular}

\section{EMPIRICAL RESEARCH}

\section{A. Structural Equation Model Theory}

There are two basic models in the structural equation model: the measurement model and the structural model. The measurement model consists of latent variables and observed variables, which is a linear function of a group of observed variables, which is generally called verification factor analysis. The measurement model is usually written as follows:

$$
\begin{aligned}
& X=\Lambda_{X} \xi+\delta \\
& Y=\Lambda_{Y} \eta+\varepsilon
\end{aligned}
$$

$\mathrm{X}$ represents a vector consisting of measurable variables of exogenous latent variables. Y represents a vector consisting of measurable variables of endogenous latent variables. $\Lambda_{X}$ and
$\Lambda_{Y}$ are the factor loading of measurable variables $(\mathrm{X}, \mathrm{Y}) ; \xi$

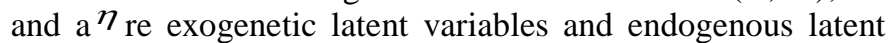
variables respectively; $\delta$ and a $\varepsilon_{\text {re measurement errors for }}$ latent variables.

The structural model is a description of the causal relationship between potential variables. It is equivalent to the traditional path analysis and is generally written as follows:

$$
\eta=B \eta+\Gamma \xi+\zeta
$$

B denotes the endogenous latent variables coefficient matrix; $\Gamma$ expresses the exogenetic latent variables coefficient matrix; $\zeta$ is the disturbing variable of the structural model, indicating the endogenous latent variables cannot be explained by exogenous latent variables and other endogenous latent variables. 


\section{B. Model Fitting}

\section{1) Model Fitting Test}

Based on the above principles, the model was fitted using Amos 20.0 software. Using Maximum Likelihood Estimation (ML), the absolute fitting index and value-added fitting index were used to evaluate the model fit. From the fitting test results of the structural equation model, we know that the chi-square value is 175.671 and the significant probability $\mathrm{p}$ is 0.000 . We reject the null hypothesis and theoretically believe that the model fit is not good, but scholar Rigdon believed that when using real-world data to evaluate theoretical model, the chi-squared statistics was usually not helpful, because chi-squared value greatly influenced by estimated parameter sample. The more parameters that are estimated, the poorer the model fit is. At this time, the fitness of the overall model should refer to other indicators. RMSEA is 0.052, indicating that the fit is good; other fitness indicators such as IFI, CFI, GFI, NFI have reached the ideal state of fitness, only AGFI and TFI are slightly lower than the standard value, but basically does not affect the overall model fit. The above shows that the fit of the entire model is good, as shown in Table IV.

TABLE IV. MODEL FIT TEST RESULTS

\begin{tabular}{|c|cccc|}
\hline $\begin{array}{c}\text { Goodness of } \\
\text { fit indicator }\end{array}$ & $\begin{array}{c}\text { Index } \\
\text { classificatio } \\
\text { n }\end{array}$ & $\begin{array}{c}\text { Evaluation } \\
\text { standard }\end{array}$ & $\begin{array}{c}\text { Model } \\
\text { results }\end{array}$ & $\begin{array}{c}\text { Evaluation of } \\
\text { results }\end{array}$ \\
\hline & $\chi^{2}$ & $\mathrm{p}>0.05$ & $\mathrm{P} \leq 0.000$ & poor \\
$\begin{array}{c}\text { Absolute fitting } \\
\text { indicator }\end{array}$ & GFI & $>0.9$ & 0.91 & better \\
& AGFI & $>0.9$ & 0.89 & slightly lower \\
\hline $\begin{array}{c}\text { Value-added } \\
\text { fitting } \\
\text { indicator }\end{array}$ & RMSEA & $<0.05$ & 0.046 & better \\
& NLI & $>0.9$ & 0.97 & better \\
& IFI & $>0.9$ & 0.95 & better \\
& CFI & $>0.9$ & 0.96 & better \\
\hline
\end{tabular}

2) Model Estimation Results and Hypothesis Verification

Through parameter estimation, the path coefficient of herdsmen's human capital, family's economic level, relationship network, regular lending channel, and informal lending channel are obtained, as presented in Figure II.

From the following results, it can be seen that herdsmen's human capital has a positive effect on pastoral households' formal lending, the path coefficient is 0.21 , and the $p$-value of the path coefficient is significant at the $1 \%$ level. According to previous studies, the relationship between age and family's likelihood of obtaining loans is inverted U-shaped, meaning that middle-aged herdsmen are more likely to obtain loans [14]. Especially in formal lending, age can be used as a judgment for the borrower's ability to pay debt. In addition, the education level is the best measurement of pastoral households' human capital. It can reflect the social capabilities and surviving ability of the herdsmen households. Therefore, the formal financial institutions prefer the higher educational group, which validates the previous hypothesis $\mathrm{H} 2 \mathrm{a}$. The path coefficient of human capital to informal lending is -0.08 and doesn't pass the significant test. This is probably because relatives and friends do not pay attention to the risks posed by pastoral households on the use of funds in human-oriented pastoral China. Hypothesis $\mathrm{H} 2 \mathrm{~b}$ has not been verified.

The path coefficient of pastoral households' family economic level to formal lending is 0.61 , the p-value is less than 0.01 and that is to say, the household economic level has a significantly positive direct impact on pastoral households' formal lending. Income for the past year, deposits, and Individual business experience reflect the level of wealth of herdsmen, and the majority of the herders' requests for financing from formal financial institutions are rejected due to insufficient collateral. Herdsmen lack effective mortgages and it's not easy for formal financial institutions to collect herdsmen's credit, which makes it difficult for pastoral households with poor economic conditions to obtain formal loans, therefore the hypothesis $\mathrm{H} 2 \mathrm{c}$ is established. The path coefficient of pastoral household economic level to informal lending is 0.33 , which passes the significant test. Hypothesis $\mathrm{H} 2 \mathrm{~d}$ is established.

The path coefficient of pastoral households' relationship network to formal lending is 0.86 , which means when other conditions are established, the relationship network variable is increased by 1 unit, and the probability of herdsmen obtaining formal lending increases by 0.86 units. Communication among relatives, neighborhood friendliness and gift expenses can reflect the "quantity" of the relationship network of pastoral households and can be used as a substitute or guarantee for mortgage loans for herdsmen. The path coefficient of the pastoral households relationship network to informal lending is 0.61 , which passes the significant test. In the pastoral areas of China, the economy is underdeveloped and communication is difficult. Herdsmens life circle mainly involves relatives and neighbors, and long-term friendly exchanges have formed a stable trust relationship, which affects informal lending. Hypothesis $\mathrm{H} 2 \mathrm{e}$ is verified.

The path coefficient of herdsmen's human capital to the relationship network is 0.35 , and the p-value is less than 0.01 , so the herdsmen's human capital has a significantly positive effect on the relationship network. Life cycle theory believes that human life will experience different stages, and different social relationships will be formed at different stages. It can be seen that age and educational level inevitably affect the quantity and quality of the social network of pastoral households. Hypothesis $\mathrm{H} 3 \mathrm{a}$ is established. The family economic level has a significantly positive impact on the pastoral households' relationship network. The path coefficient is 0.56 , and the $\mathrm{p}$ - value is significant at the $1 \%$ level. Different classes of people have different economic levels, and people's social resources and social relationships are different. Hypothesis $\mathrm{H} 3 \mathrm{~b}$ is verified. Therefore, it can be induced that the herdsmen's human capital and family economic level will indirectly affect the herdsmen's knowledge and choice of lending channels through the intermediary variable, which is likely to be stronger than the direct effect of the two on herdsmen' lending channels. 


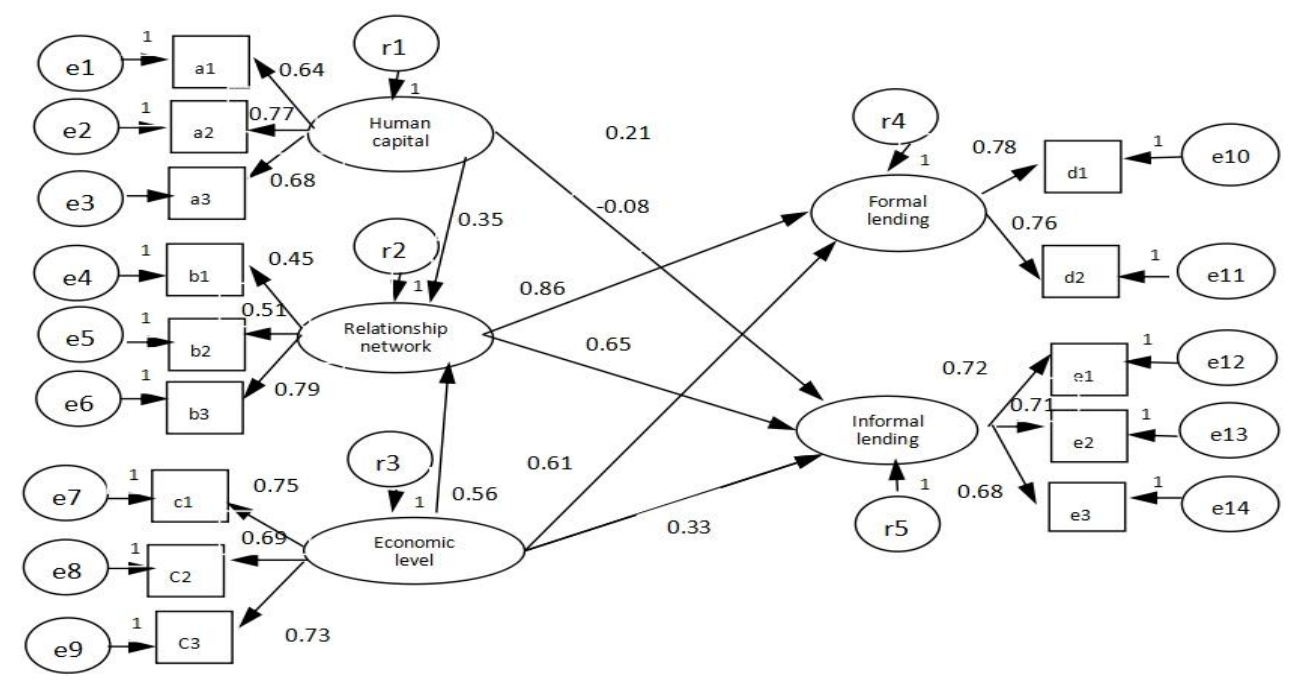

FIGURE II. MODEL FITTING PATH

To sum up, it can be concluded that there are different endowment factors and that herdsmen' lending channels are different. Herdsmen who pay attention to their own construction, their educational level, and social capabilities will increase the availability of their loans. In the past, studies have also shown that the higher the family's gross income, the better the level of education for the household, thus promoting formal financial channels for financing. The higher the degree of trust of relatives and the higher the social status of close friends, the easier it is to obtain informal finance [15]. Therefore, hypothesis $\mathrm{H} 2$ is established, and thus hypothesis $\mathrm{H} 1$ is also established. The hypothetical results of this paper are shown in Table V.

TABLE V. MODEL HYPOTHESIS TEST RESULTS

\begin{tabular}{|c|c|c|c|c|}
\hline Relationship path & $\begin{array}{c}\text { Hypot } \\
\text { hesis }\end{array}$ & $\begin{array}{c}\text { Standardized } \\
\text { path coefficient }\end{array}$ & P-value & conclusion \\
\hline $\begin{array}{c}\text { Human capital } \rightarrow \\
\text { Regular lending } \\
\text { channels }\end{array}$ & $\mathrm{H} 2 \mathrm{a}$ & 0.21 & $* * *$ & support \\
\hline $\begin{array}{l}\text { Human capital } \rightarrow \\
\text { Informal lending } \\
\text { channels }\end{array}$ & $\mathrm{H} 2 \mathrm{~b}$ & -0.08 & $* * *$ & Not support \\
\hline $\begin{array}{c}\text { Family economic } \\
\text { level } \rightarrow \text { Formal } \\
\text { lending channels }\end{array}$ & $\mathrm{H} 2 \mathrm{c}$ & 0.61 & $* * *$ & support \\
\hline $\begin{array}{l}\text { Family economic } \\
\text { level } \rightarrow \text { Informal } \\
\text { lending channels }\end{array}$ & $\mathrm{H} 2 \mathrm{~d}$ & 0.33 & $* * *$ & support \\
\hline $\begin{array}{c}\text { Relationship } \\
\text { network } \rightarrow \text { Regular } \\
\text { lending channels }\end{array}$ & $\mathrm{H} 2 \mathrm{e}$ & 0.86 & $* * *$ & support \\
\hline $\begin{array}{c}\text { Relationship } \\
\text { network } \rightarrow \text { Informal } \\
\text { lending Channels }\end{array}$ & $\mathrm{H} 2 \mathrm{e}$ & 0.65 & $* * *$ & support \\
\hline $\begin{array}{l}\text { Human capital } \rightarrow \\
\text { Relational network }\end{array}$ & $\mathrm{H} 3 \mathrm{a}$ & 0.35 & $* * *$ & support \\
\hline $\begin{array}{c}\text { Family economic } \\
\text { level } \rightarrow \text { Relational } \\
\text { network }\end{array}$ & $\mathrm{H} 3 \mathrm{~b}$ & 0.56 & $* * *$ & support \\
\hline
\end{tabular}

*** indicates $\mathrm{p} \leq 0.001$

\section{RESEARCH CONCLUSIONS AND IMPLICATIONS}

Based on the survey data of 1191 pastoral households, this paper constructs a structural equation model to analyze the impact path and the mechanism of pastoral households endowments on their financing channels. The results of the study show that rich endowments have a positive impact on herdsmen' access to loans, and that the more abundant human capital herdsmen have, the easier it is to obtain formal lending, but it has no significant effect on informal lending; family economic level has a significant impact on formal lending and informal lending, and it is more advantageous for herdsmen to obtain formal lending than informal lending; herdsmen's relationship network has a significantly positive effect on herdsmen' s access to formal lending and informal lending. In addition, herdsmen's human capital and the family economic level have a strengthening effect on the herdsmen's relationship network, and indirectly affect the herdsmen's lending channels.

According to the research conclusions of this article, the following policy recommendations can be put forward: Firstly, continuously strengthen the understanding and exchanges between various lending entities, fully use the information advantages of informal finance, use the trust mechanism that depends on the relationship network in private lending and formal lending. Secondly, it's not easy for those pastoral households with lower incomes and lower education levels to obtain formal loans. Through increasing expenditures on modern technology training for herdsmen, herdsmen should be guided to develop science and technology husbandry so as to increase their income. Thirdly, because of the great differences in endowment factors of pastoral households and the various demand for loans, use the method to provide financial products that are suitable for pastoral realities and herdsmen' needs through innovation will greatly increase the practical effect of poverty alleviation and poverty reduction. Lastly, actively explore the establishment of a pastoral asset mortgage market, encourage formal financial institutions to establish a value appraisal system for pastoral asset collateral, vigorously promote farmland ownership, and improve the herdsmen's formal credit availability. 


\section{ACKNOWLEDGEMENT}

The research is supported by the Inner Mongolia Science and Technology Department Soft Science Project of China (201505047) and Inner Mongolia Institute of Rural Pastoral Development of China(201801001). We would like to express our sincere gratitude to the organizations mentioned above.

\section{REFERENCES}

[1] LinLu. Study on the Influence of Family Endowment on Farmers' Loan Behavior--Based on the 2012 China Labour Dynamic Survey Data (CLDS) [D]. Southwest University of Finance and Economics, 2016.

[2] Daihui Si. Empirical research on the influence of farmers' differentiation and social capital on lending behavior — A case study of Hengshan District, Yulin City [D]. Northwest A\&F University, 2017.

[3] Glass.D.V. Social Mobility in Britain. London: Routedge \& Kegan Paul Edition, 1954

[4] Maria C. Pereira; Filipe Coelho; Óscar Lourenço. Who Feels Credit Constrained in Europe? The Role of Social Capital[J]. 2017(8): 380-405.

[5] Xiangzhi Kong, Songhai Fang, Xiaopeng Pan, Jiujie Ma. Analysis of Influence of Farmers' Endowment on the Adoption of Agricultural Technology in the Western Region [J].Economic Research, 2004(12): 85-95.

[6] Zhilei Shi, ChiYu. Research on Family Endowment, Human Capital and Women's Employment Flow in Urban and Rural Areas--Urban and Rural Survey Data from Hubei Province[J]. Agricultural Economic Issues, 2011 (12):81-90.

[7] Zan Yang; Ying Fan; Jing Wu. Informal Borrowing and Home Purchase: Evidence from Urban China[J]. Regional Science and Urban Economics, 2017.

[8] George Okello Candiya Bongomin; John C. Munene; Joseph Mpeera Ntayi; Charles Akol Malinga. Exploring the mediating role of social capital in the relationship between financial intermediation and financial inclusion in rural Uganda[J].2018:829-847.

[9] BeIl.C. Interaction between institutional and informal credit agencies in rural India[J].World Bank Economic Review,1990(3):297-327.

[10] Aleem, I. Imperfect information, screening, and the costs of informal lending: A Study of a rural credit market in Pakistan. World Bank Economic Review, 1990(3): 329-349.

[11] Tho Pham; Oleksandr Talavera. Discrimination, Social Capital, and Financial Constraints: The Case of VietNam[J]. World Development, 2018: 228-242.

[12] Qinghua Chen. The Impact of Village Development Mutual Aid Funds on Farmers' Agricultural Production Investment and Income-Based on Empirical Evidence from 655 Farmers in 37 Poor Villages in 13 Counties in Ningxia[J].Journal of Nanjing Agricultural University (Social Science Edition), 2017(04):138-146.

[13] Xinle Tong, Baojin Chun, Xiangyang Yang. An Empirical Study on the Impact of Social Capital on Farmers' Loan Behavior-Based on Survey Data of 1003 Households in Eight Provinces[J]. Financial Research, 2011(12):177-191.

[14] YeJin, Hongbin Li. Informal Finance and Farmers' Borrowing Behavior[J]. financial research, 2009, (4):63-7

[15] Wendy Stone. Measuring social capital[J]. Research Paper No.24, 2001.02

[16] Cindy-Ann Bryant and Doug Norris. Measurement of Social Capital: The Canadian Experience [J]. Statistics Canada, 2002.08. 